\title{
Perencanaan Penanggulangan Banjir Akibat Luapan Sungai Petung, Kota Pasuruan, Jawa Timur
}

\author{
Aninda Rahmaningtyas, Umboro Lasminto, Bambang Sarwono, \\ Departemen Teknik Sipil, Fakultas Teknik Sipil dan Perencanaan, Institut Teknologi Sepuluh \\ Nopember (ITS) \\ e-mail: anindarahmaningtyas1995@gmail.com, umboro_hydro@yahoo.com,bambang_s@ce.its.ac.id
}

\begin{abstract}
Abstrak-Kota Pasuruan berada di jalur utama pantai utara yang menghubungkan Pulau Jawa dan Pulau Bali. Terdapat tiga sungai yang melewati Kota Pasuruan, salah satunya Sungai Petung. Ketika musim hujan tiba, beberapa daerah di Kota Pasuruan tergenang akibat luapan Sungai Petung. Genangan terbesar terjadi setinggi 1,50 meter dan alur pantura tidak dapat dilalui kendaraan. Permasalahan ini diselesaikan dengan cara melakukan analisis hidrologi, hidrolika, dan perencanaan bangunan pengendali banjir. Analisis hidrologi berupa cara mengolah data hujan, hingga diperoleh debit banjir rencana 25 tahunan. Analisis hidrolika berupa pengolahan data pasang surut yang kemudian dilakukan simulasi dengan program bantu HECRAS untuk mengetahui kapasitas Sungai Petung. Data yang dibutuhkan untuk simulasi HEC-RAS antara lain data pasang surut, debit banjir rencana 25 tahunan, dan detail cross section Sungai Petung. Setelah diketahui kapasitas Sungai Petung, maka langkah selanjutnya merencanakan bangunan penanggulangan banjir. Dari hasil simulasi diketahui bahwa terjadi luapan dari STA 134-0. Bangunan pengendali banjir yang digunakan berupa tanggul. Direncanakan tanggul sepanjang $5,93 \mathrm{~km}$ dengan kemiringan lereng tanggul 1:1, lebar mercu sebesar 3 meter, tinggi tanggul mulai dari 3 sampai 5 meter, dan tinggi jagaan sebesar 0,80 meter dari Sta 134 - Sta 0. Sehingga luapan Sungai Petung dapat ditanggulangi.
\end{abstract}

Kata kunci-Banjir, Tanggul, Sungai Petung, HEC-RAS.

\section{PENDAHULUAN}

$\mathrm{K}$ OTA Pasuruan terletak $60 \mathrm{~km}$ di sebelah tenggara Surabaya dan memiliki luas $147 \mathrm{~km}^{2}$. Kota Pasuruan berada di jalur utama pantai utara yang menghubungkan Pulau Jawa dan Pulau Bali. Pada tanggal 11 Oktober 2016 jalur yang menghubungkan kota Pasuruan terputus, akibatnya bus, truk, dan kendaraan pribadi yang menuju probolinggo dari arah Surabaya dan Pasuruan tidak dapat dilalui. Hal ini dikarenakan terjadinya genangan ketika curah hujan yang cukup tinggi di wilayah tersebut.

Data dari Dinas Pekerjaan Umum bagian Drainase menunjukkan terdapat empat titik genangan dan salah satunya di kawasan timur Kota Pasuruan (gambar 1.1). Di kawasan Timur Kota Pasuruan terdapat Sungai Petung yang berpengaruh terhadap terjadinya genangan di daerah tersebut. Luas genangannya sebesar 4.32 Ha. Terdapat tiga kemungkinan penyebab terjadinya genangan. Pertama, kapasitas Sungai Petung yang tidak mampu menerima debit banjir saat ini. Kedua, saluran drainase di wilayah genangan tidak dapat menampung air hujan yang terjadi. Ketiga, akibat elevasi pembuang yang lebih rendah mengakibatkan backwater pada Sungai Petung akibat pasang surut air laut.

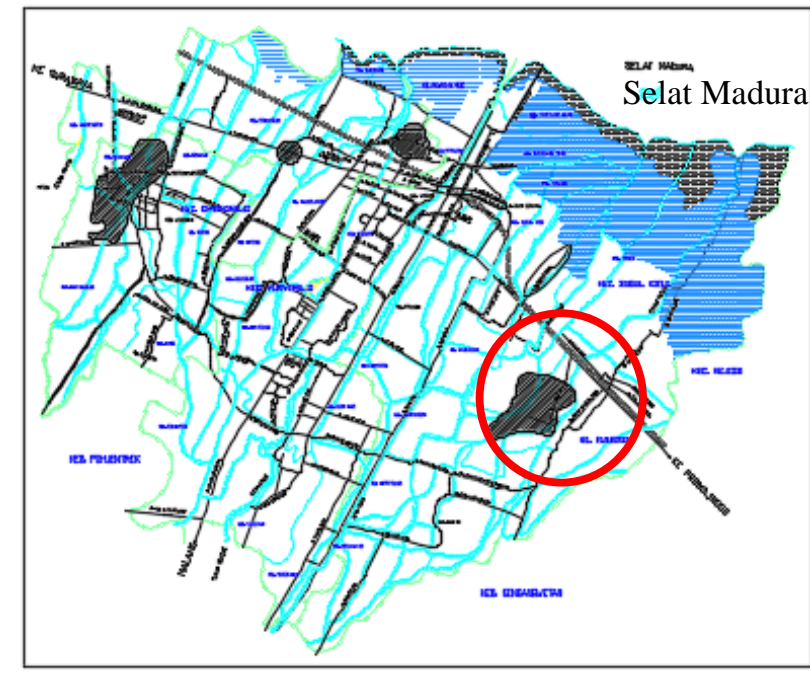

Gambar 1. Peta Genangan Kota Pasuruan. (PU Kota Pasuruan,2012).

Upaya untuk mengatasi masalah genangan yang terjadi yaitu dengan merencanakan jaringan drainase di daerah aliran Sungai Petung, Kota Pasuruan agar mampu menerima debit banjir yang terjadi. Dengan merencanakan jaringan drainase diharapkan air hujan dapat ditampung pada saluran drainase dan selanjutnya dialirkan menuju Sungai Petung tanpa terjadi genangan. Oleh karena itu Studi ini dibuat.

\section{METODOLOGI}

Metode yang digunakan dalam penyusunan Studi adalah sebagai berikut : 


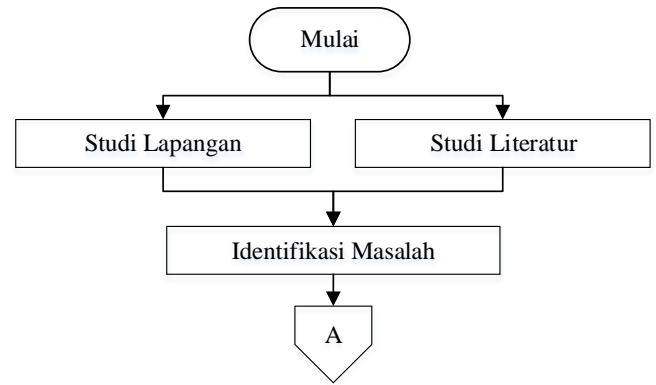

Gambar 2. Diagram Alir Metodologi.

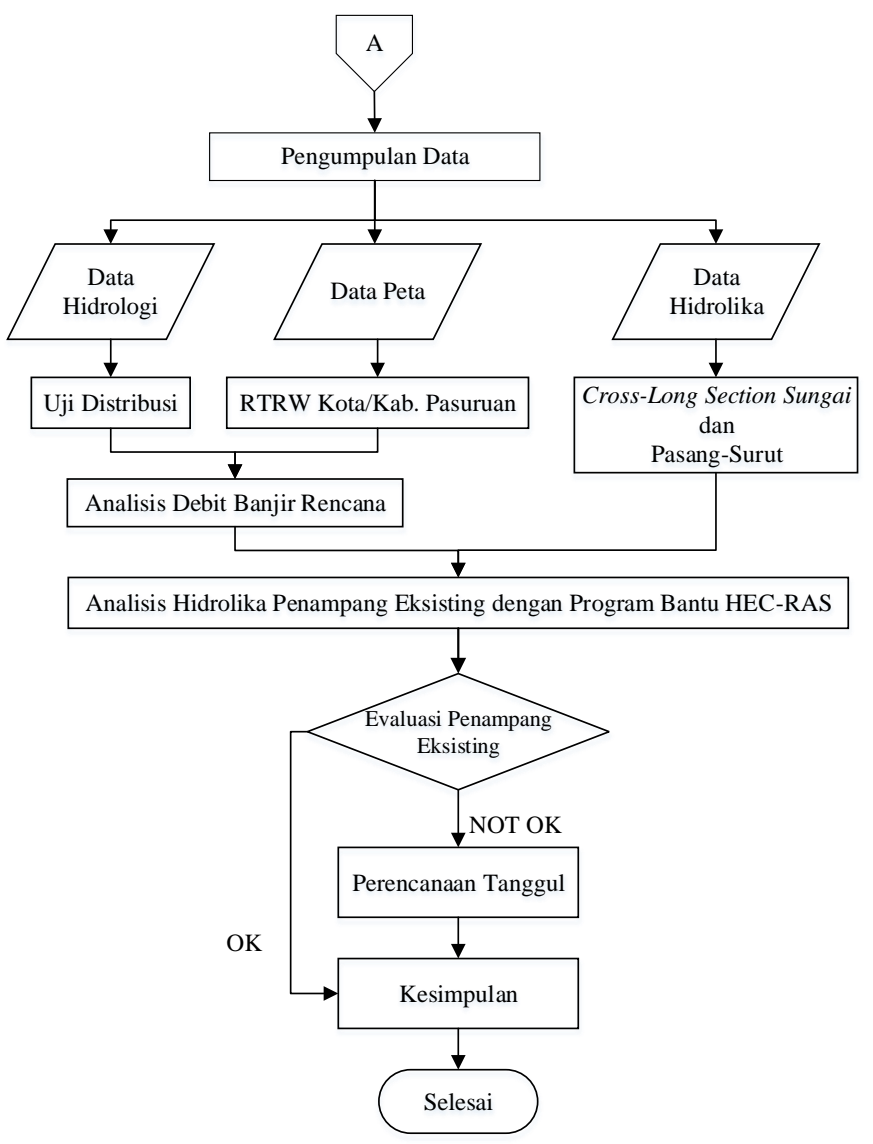

Gambar 3. Diagram Alir Metodologi.

\section{HASIL DAN PEMBAHASAN}

\section{A. Analisis Hidrologi}

Analisis HIdrologi dilakukan untuk mengetahui parameterparameter hidrologi, berupa karakteristik hujan, menganalisis hujan rencana dan analisis debit rencana.

1. Penentuan Hujan Wilayah

Terdapat 4 stasiun hujan yang berpengaruh terhadap Daerah Aliran Sungai Petung, dan diperoleh menggunakan metode Thiessen [1], gambar 4. Keempat stasiun hujan tersebut adalah stasiun hujan P3GI, Puspo, Tutur, dan Orooro Pule. Jika terdapat stasiun hujan serta luasan pengaruh setiap stasiun hujan, tabel 1, maka akan diperoleh koefisien untuk menentukan tinggi hujan maksimum setiap tahunnya, Tabel 2.
Tabel 1.

Luasan yang Mewakili tiap Stasiun Hujan

\begin{tabular}{clc}
\hline \hline No. & \multicolumn{1}{c}{ Stasiun Hujan } & Luas $\left(\mathbf{k m}^{\mathbf{2}}\right)$ \\
\hline 1 & P3GI $\left(\mathrm{A}_{1}\right)$ & 10,33 \\
2 & Puspo $\left(\mathrm{A}_{2}\right)$ & 69,05 \\
3 & Tutur $\left(\mathrm{A}_{3}\right)$ & 33,14 \\
4 & Oro-oro Pule $\left(\mathrm{A}_{4}\right)$ & 37,11 \\
& Jumlah & 149,63 \\
\hline \hline
\end{tabular}

Tabel 2.

Tinggi Hujan Rata-rata Maksimum

\begin{tabular}{cc}
\hline \hline Tahun & Tinggi Hujan $(\mathbf{m m})$ \\
\hline 2004 & 42,13 \\
2005 & 57,32 \\
2006 & 68,69 \\
2007 & 80,03 \\
2008 & 117,58 \\
2009 & 59,90 \\
2010 & 65,98 \\
2011 & 54,66 \\
2012 & 61,86 \\
2013 & 72,48 \\
2014 & 72,99 \\
2015 & 109,55 \\
\hline \hline
\end{tabular}

(Hasil Perhitungan)

Gambar 4. Polygon Thiessen pada DAS Petung.

2. Perhitungan Parameter Statistik

Analisis tinggi hujan rencanan menggunakan metode normal, gumbel, log-normal, dan log-pearson III [2], Tabel 2 dan tabel 3.

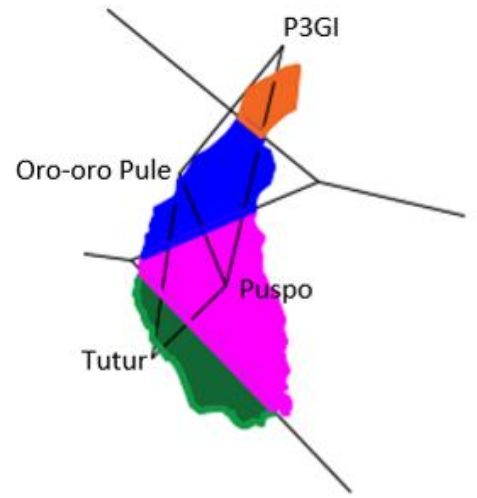

Tabel 3.

Perhitungan Parameter Statistik untuk Distribusi Normal dan Gumbel

\begin{tabular}{|c|c|c|c|c|c|c|c|}
\hline No & $\begin{array}{c}\text { Tahu } \\
\text { n }\end{array}$ & $\underset{(\mathbf{m m})}{\mathbf{X}}$ & $\bar{X}$ & $\begin{array}{l}\mathbf{X}- \\
\bar{X}\end{array}$ & $(X-\bar{X})^{2}$ & $(X-\bar{X})^{3}$ & $(X-\bar{X})^{4}$ \\
\hline 1 & 2015 & $\begin{array}{c}117,5 \\
8\end{array}$ & $\begin{array}{c}71,9 \\
3\end{array}$ & 45,65 & 2083,68 & 95114,55 & $\begin{array}{c}4341727,7 \\
0\end{array}$ \\
\hline 2 & 2008 & $\begin{array}{c}109,5 \\
5\end{array}$ & $\begin{array}{c}71,9 \\
3\end{array}$ & 37,62 & 1415,17 & 53236,67 & $\begin{array}{c}2002693,7 \\
5\end{array}$ \\
\hline 3 & 2014 & 80,03 & $\begin{array}{c}71,9 \\
3\end{array}$ & 8,10 & 65,58 & 531,02 & 4300,14 \\
\hline 4 & 2007 & 72,99 & $\begin{array}{c}71,9 \\
3\end{array}$ & 1,06 & 1,13 & 1,21 & 1,29 \\
\hline 5 & 2013 & 72,48 & $\begin{array}{c}71,9 \\
3\end{array}$ & 0,55 & 0,30 & 0,17 & 0,09 \\
\hline 6 & 2012 & 68,69 & $\begin{array}{c}71,9 \\
3\end{array}$ & $-3,24$ & 10,53 & $-34,16$ & 110,84 \\
\hline 7 & 2010 & 65,98 & $\begin{array}{c}71,9 \\
3\end{array}$ & $-5,95$ & 35,37 & $-210,39$ & 1251,35 \\
\hline
\end{tabular}




\begin{tabular}{|c|c|c|c|c|c|c|c|c|c|c|c|c|}
\hline 8 & 2011 & 61,86 & $\begin{array}{c}71,9 \\
3\end{array}$ & - & 101,41 & $-1021,27$ & 10284,64 & \multicolumn{5}{|c|}{$\begin{array}{c}\text { Tabel } 5 . \\
\text { Uji Chi-Square Distribusi Log-Pearson III } \\
\end{array}$} \\
\hline \multirow[t]{2}{*}{9} & 2006 & 59,90 & 71,9 & - & 144,66 & $-1739,82$ & 20925,39 & Batas Sub Grup & 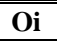 & $\overline{\mathbf{E i}}$ & $(\mathbf{O} \mathbf{O i}-\mathbf{E i}) 2$ & $(\mathbf{O i}-\mathbf{E i}) 2 / \mathbf{E i}$ \\
\hline & & & 3 & 12,03 & & & & $X>87,11$ & 2 & 2,4 & 0,16 & 0,0667 \\
\hline 10 & 2005 & 57,32 & 71,9 & - & 213,52 & $-3120,00$ & 45590,28 & $87,11>X \geq 70,52$ & 3 & 2,4 & 0,36 & 0,1500 \\
\hline 11 & 2004 & 54,66 & $\begin{array}{c}3 \\
71,9 \\
3\end{array}$ & $\begin{array}{c}14,61 \\
- \\
17,27\end{array}$ & 298,37 & $-5153,73$ & 89021,69 & $\begin{array}{l}70,52>X \geq 65,74 \\
65,74>X \geq 63,44\end{array}$ & $\begin{array}{l}2 \\
0\end{array}$ & $\begin{array}{l}2,4 \\
2,4\end{array}$ & $\begin{array}{l}0,16 \\
5,76\end{array}$ & $\begin{array}{l}0,0667 \\
2,400\end{array}$ \\
\hline 12 & 2009 & 42,13 & $\begin{array}{c}71,9 \\
3\end{array}$ & 29,80 & 888,28 & $-26474,13$ & 789033,81 & $\begin{array}{c}\mathrm{X}<63,44 \\
\text { Jumlah } \\
\end{array}$ & $\begin{array}{c}5 \\
12 \\
\end{array}$ & $\begin{array}{l}2,4 \\
12 \\
\end{array}$ & 6,76 & $\begin{array}{l}2,8167 \\
5,5000 \\
\end{array}$ \\
\hline \multicolumn{2}{|c|}{ JUMLAH } & $\begin{array}{c}863,1 \\
6 \\
\end{array}$ & & & 5257,99 & $\begin{array}{c}111130,1 \\
0 \\
\end{array}$ & $\begin{array}{c}7304940, \bar{x} \\
8 \\
\end{array}$ & Can 5500 & 99 & & His & K \\
\hline
\end{tabular}

(Hasil Perhitungan)

Tinggi hujan rata-rata $=104,72 \mathrm{~mm}$

Tabel 6.
$\mathrm{S}=21,86$
$\mathrm{Cs}=1,16$
$\mathrm{Cv}=0,30$
$\mathrm{Ck}=4,65$

Tabel 4.

Perhitungan Parameter Statistik untuk Distribusi Log-Normal dan Log Pearson III

\begin{tabular}{ccccccc}
\hline \hline No & Tahun & $\begin{array}{c}\text { X } \\
(\mathbf{m m})\end{array}$ & $\begin{array}{c}\text { Log } \\
(\mathbf{X})\end{array}$ & $\begin{array}{c}\text { Log } \\
(X-\bar{X})^{2}\end{array}$ & $\begin{array}{c}\text { Log } \\
(X-\bar{X})^{3}\end{array}$ & $\begin{array}{c}\text { Log } \\
(X-\bar{X})^{4}\end{array}$ \\
\hline 1 & 2015 & 117,58 & 2,0703 & 0,0530 & 0,0122 & 0,0028 \\
2 & 2008 & 109,55 & 2,0396 & 0,0398 & 0,0079 & 0,0016 \\
3 & 2014 & 80,03 & 1,9032 & 0,0040 & 0,0003 & 0,0000 \\
4 & 2007 & 72,99 & 1,8633 & 0,0005 & 0,0000 & 0,0000 \\
5 & 2013 & 72,48 & 1,8602 & 0,0004 & 0,0000 & 0,0000 \\
6 & 2012 & 68,69 & 1,8369 & 0,0000 & 0,0000 & 0,0000 \\
7 & 2010 & 65,98 & 1,8194 & 0,0004 & 0,0000 & 0,0000 \\
8 & 2011 & 61,86 & 1,7914 & 0,0024 & $-0,0001$ & 0,0000 \\
9 & 2006 & 59,90 & 1,7774 & 0,0039 & $-0,0002$ & 0,0000 \\
10 & 2005 & 57,32 & 1,7583 & 0,0067 & $-0,0005$ & 0,0000 \\
11 & 2004 & 54,66 & 1,7376 & 0,0105 & $-0,0011$ & 0,0001 \\
12 & 2009 & 42,13 & 1,6245 & 0,0465 & $-0,0100$ & 0,0022 \\
JUMLAH & & 22,082 & 0,1681 & 0,0084 & 0,0067 \\
\hline \hline
\end{tabular}

(Hasil Perhitungan)

$\mathrm{S} \quad=0,1236$

$\mathrm{Cs}=0,50$

$\mathrm{Cv}=0,0672$

$\mathrm{Ck}=4,1979$

Dari parameter tersebut, dipilih jenis distribusi yang sesuai,tabel 4.

Tabel 5.

Pemilihan Jenis Distribusi

\begin{tabular}{|c|c|c|c|}
\hline Distribusi & Persyaratan & $\begin{array}{c}\text { Hasil } \\
\text { Perhitungan }\end{array}$ & Kesimpulan \\
\hline \multirow{2}{*}{ Normal } & $\mathrm{Cs}_{\mathrm{s}} \approx 0$ & $\mathrm{Cs}_{\mathrm{S}}=1,16$ & NO \\
\hline & $\mathrm{C}_{\mathrm{K}} \approx 3$ & $\mathrm{C}_{\mathrm{K}}=4,65$ & NO \\
\hline \multirow[t]{2}{*}{ Log Normal } & $\mathrm{C}_{\mathrm{S}}=0,15$ & $\mathrm{C}_{\mathrm{S}}=0,50$ & NO \\
\hline & $\mathrm{C}_{\mathrm{K}}=3,04$ & $\mathrm{C}_{\mathrm{K}}=4,1979$ & NO \\
\hline \multirow[t]{2}{*}{ Gumbel } & $\mathrm{C}_{\mathrm{S}}=1,14$ & $\mathrm{Cs}_{\mathrm{S}}=1,16$ & NO \\
\hline & $\mathrm{C}_{\mathrm{K}}=5,40$ & $\mathrm{C}_{\mathrm{K}}=4,65$ & NO \\
\hline \multirow[t]{2}{*}{ Log Pearson III } & Selain dari nilai di & $\mathrm{Cs}=0,50$ & $\mathrm{OK}$ \\
\hline & atas & $\mathrm{C}_{\mathrm{K}}=4,1979$ & $\mathrm{OK}$ \\
\hline
\end{tabular}

Pada tabel 4 disimpulkan hanya distribusi Log Pearson III yang dapat digunakan. Langkah selanjutnya dilakukan uji kecocokan Chi-Square dan Smirnov Kolmogorov untuk menetuka distribusi tersebut cocok atau tidak, tabel 5 dan 6 .
Uji Smirnov Kolmogorov Distribusi Log-Pearson III

\begin{tabular}{cccccccc}
\hline \hline $\mathbf{Y}$ & $\mathbf{M}$ & $\mathbf{P}(\mathbf{X})$ & $\mathbf{P}(\mathbf{X}<)$ & $\mathbf{f}(\mathbf{t})$ & $\mathbf{P}^{\prime}(\mathbf{X}<)$ & $\mathbf{P}^{\prime}(\mathbf{X})$ & $\mathbf{D}$ \\
\hline 2,07 & 1 & 0,0769 & 0,9231 & 1,86 & 0,9686 & 0,0314 & 0,0455 \\
2,04 & 2 & 0,1538 & 0,8462 & 1,61 & 0,9463 & 0,0537 & 0,1001 \\
1,90 & 3 & 0,2308 & 0,7692 & 0,51 & 0,6950 & 0,3050 & 0,0742 \\
1,86 & 4 & 0,3077 & 0,6923 & 0,19 & 0,5753 & 0,4247 & 0,1170 \\
1,86 & 5 & 0,3846 & 0,6154 & 0,16 & 0,5636 & 0,4364 & 0,0518 \\
\hline \hline
\end{tabular}

Tabel 6.

\begin{tabular}{cccccccc}
\multicolumn{10}{c}{ (Lanjutan) Uji Smirnov Kolmogorov Distribusi Log-Pearson III } \\
1,84 & 6 & 0,4615 & 0,5385 & $-0,03$ & 0,4880 & 0,5120 & 0,0505 \\
1,82 & 7 & 0,5385 & 0,4615 & $-0,17$ & 0,4325 & 0,5675 & 0,0290 \\
1,79 & 8 & 0,6154 & 0,3846 & $-0,39$ & 0,3483 & 0,6517 & 0,0363 \\
1,78 & 9 & 0,6923 & 0,3077 & $-0,51$ & 0,3050 & 0,6950 & 0,0027 \\
1,76 & 10 & 0,7692 & 0,2308 & $-0,66$ & 0,2546 & 0,7454 & 0,0238 \\
1,74 & 11 & 0,8462 & 0,1538 & $-0,83$ & 0,2033 & 0,7967 & 0,0495 \\
1,62 & 12 & 0,9231 & 0,0769 & $-1,74$ & 0,0409 & 0,9591 & 0,0360 \\
& & & & & & Dmax & 0,1170 \\
\hline
\end{tabular}

(Hasil Perhitungan)

Do $=0,3663>$ Dmax $=0,1170 \ldots$ OK

Kesimpulan yang diperoleh dari tabel 5 dan 6 adalah distribusi log-Pearson III dapat digunakan. Selanjutnya tinggi hujan rencan dengan periiode ulang yang ditentukan dapat dihitung, tabel 7 .

Tabel 7.

Tinggi Hujan Rencana Tiap Periode Ulang

\begin{tabular}{cc}
\hline \hline $\begin{array}{c}\text { Periode Ulang } \\
\text { (Tahun) }\end{array}$ & Tinggi Hujan $(\mathbf{m m})$ \\
\hline 5 & 88,31 \\
10 & 100,87 \\
20 & 112,75 \\
25 & 119,21 \\
50 & 133,63 \\
100 & 148,68 \\
\hline \hline
\end{tabular}

(Hasil Perhitungan)

3. Analisis Debit Banjir Rencana

Analisis Debit Banjir Rencana menggunakan metode Nakayasu [3]. Periode ulang yang digunakan untuk perencanaan sungai yaitu periode ulang 25 tahunan. Perhitungan debit banjir menggunakan metode Nakayasu membutuhkan nilai koefisien pengaliran. Untuk mengetahui nilai koefisien pengaliran dengan cara melihat peta Rencana Tata Ruang Wilayah Kota dan Kabupaten Pasuruan [4]. Peta RTRW dapat dilihat pada gambar 5, dan 6. Sebelum menentukan nilai debit banjir rencana, diperoleh nilai unit hidrograf [5], tabel 7 Hasilnya dapat dilihat pada tabel 9, gambar 7 . 


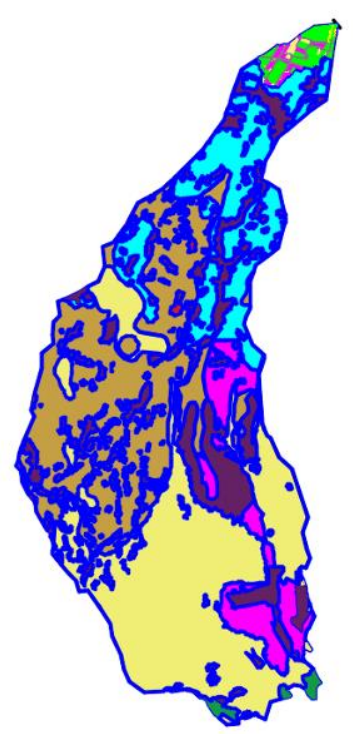

Gambar 5. RTRW Kota/Kabupaten Pasuruan.

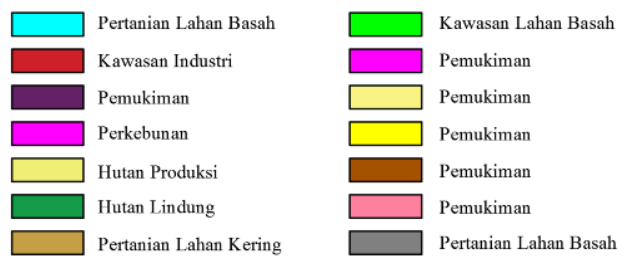

Gambar 6. Legenda Peta RTRW Kota/Kabupaten Pasuruan.

Tabel 8.

Unit Hidrograf Koreksi Metode Nakayasu

\begin{tabular}{cccc}
\hline \hline $\mathbf{t}(\mathbf{j a m})$ & $\mathbf{Q}\left(\mathbf{m}^{\mathbf{3} / \mathbf{s})}\right.$ & $\mathbf{t}(\mathbf{j a m})$ & $\begin{array}{c}\mathbf{Q} \\
\left(\mathbf{m}^{\mathbf{3}} / \mathbf{s}\right)\end{array}$ \\
\hline 0 & 0 & 15 & 79.719 \\
1 & 184,05 & 16 & 72.791 \\
2 & 1155,49 & 17 & 65.730 \\
3 & 3542,03 & 18 & 59.354 \\
4 & 7697,87 & 19 & 53.596 \\
& 12755,1 & 20 & 48.397 \\
4.72 & 5 & & \\
& 14933,6 & 21 & 43.702 \\
5 & 3 & & \\
& 13574,6 & 22 & 39.462 \\
6 & 7 & & \\
& 11648,1 & 23 & 35.634 \\
7 & 1 & & 32.177 \\
8 & 9994,97 & 24 & 29.723 \\
9 & 8576,46 & 24.4 & 27.817 \\
10 & 7359,26 & 25 & 26.035 \\
11 & 6314,81 & 26 & 24.421 \\
12 & 5418,59 & 27 & 22.742 \\
12.6 & 4790,21 & 28 & 21.066 \\
13 & 4480,96 & 29 & 19.514 \\
14 & 4173,46 & 30 &
\end{tabular}

(Hasil Perhitungan)

Tabel 9.

Hasil Hidrograf dengan Metode Nakayasu

\begin{tabular}{cccc}
\hline \hline $\mathbf{t}(\mathbf{j a m})$ & $\mathbf{Q}\left(\mathbf{m}^{\mathbf{3} / \mathbf{s})}\right.$ & $\mathbf{t}(\mathbf{j a m})$ & $\mathbf{Q}\left(\mathbf{m}^{\mathbf{3}} \mathbf{s}\right)$ \\
\hline 0 & 0 & 15 & 64.674 \\
1 & 2.382 & 16 & 59.054 \\
2 & 14.071 & 17 & 53.325 \\
3 & 42.327 & 18 & 48.152 \\
4 & 94.289 & 19 & 43.481 \\
4.72 & 161.479 & 20 & 39.263 \\
5 & 201.812 & 21 & 35.454 \\
\hline \hline
\end{tabular}

Tabel 9.

(Lanjutan) Hasil Hidrograf dengan Metode Nakayasu

\begin{tabular}{cccc}
\hline \hline $\mathbf{t}(\mathbf{j a m})$ & $\mathbf{Q}\left(\mathbf{m}^{\mathbf{3}} / \mathbf{s}\right)$ & $\mathbf{t}(\mathbf{j a m})$ & $\mathbf{Q}\left(\mathbf{m}^{\mathbf{3}} / \mathbf{s}\right)$ \\
\hline 6 & 214.454 & 22 & 32.015 \\
7 & 205.327 & 23 & 28.909 \\
8 & 180.091 & 24 & 26.105 \\
9 & 154.532 & 24.4 & 24.113 \\
10 & 132.600 & 25 & 22.567 \\
11 & 113.781 & 26 & 21.121 \\
12 & 97.633 & 27 & 19.812 \\
12.6 & 85.597 & 28 & 18.450 \\
13 & 77.570 & 29 & 17.091 \\
14 & 70.585 & 30 & 15.832 \\
\hline \hline
\end{tabular}

(Hasil Perhitungan)

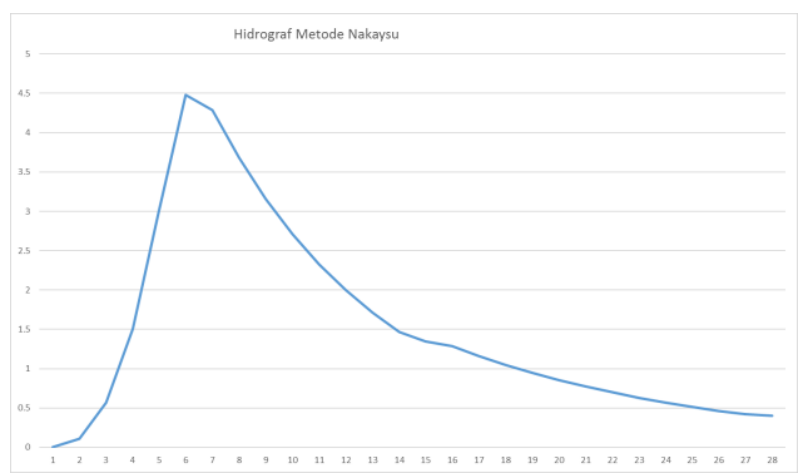

Gambar 7. Hasil Perhitungan Debit Banjir Rencan dengan Metode Nakayasu.

\section{B. Analisis Hidrolika}

Dalam perencanaan hidrolika, yang diolah adalah data pasang surut untuk mengetahui pengaruhnya terhadap Sungai Petung. Pengolahan data pasang surut menggunakan metode Admiralty [6], gambar 8.

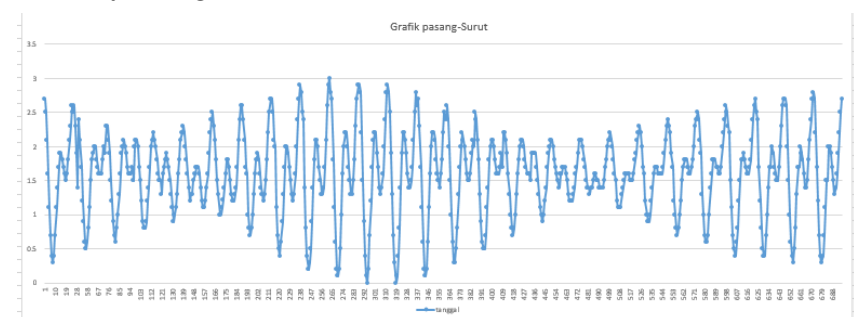

Gambar 8. Grafik Pasang Surut.

Setelah dihitung menggunakan metode Admiralty diperoleh jenis pasang surut yang terjadi, adalah pasang surut campuran dominan ganda (mixed, mainy diurnal tide) dengan nilai $\mathrm{F}$ sebesar 1,0282 [7].

\section{Permodelan dengan Program Bantu HEC-RAS}

Permodelan dengan program bantu HEC-RAS membutuhkan data berupa cross section sungai, nilai manning sungai. Nilai manning adalah nilai kekasaran saluran [8]. Pada Studi ini, digunakan simulasi unsteady flow, sehingga dibutuhkan hidrograf di bagian hulu dan digunakan data pasang surut di bagian hilir [9]. Berdasarkan hasil simulasi HEC-RAS, hasilnya dapat dilihat pada gambar 9 dan 10 . 


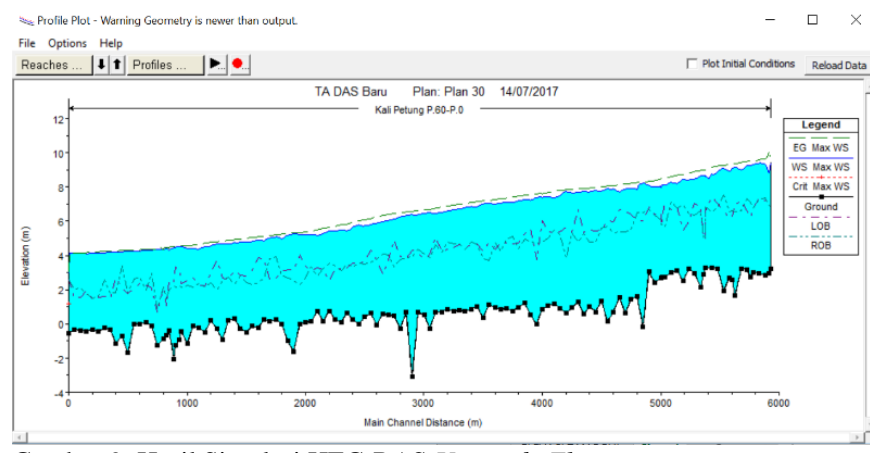

Gambar 9. Hasil Simulasi HEC-RAS Unsteady Flow.

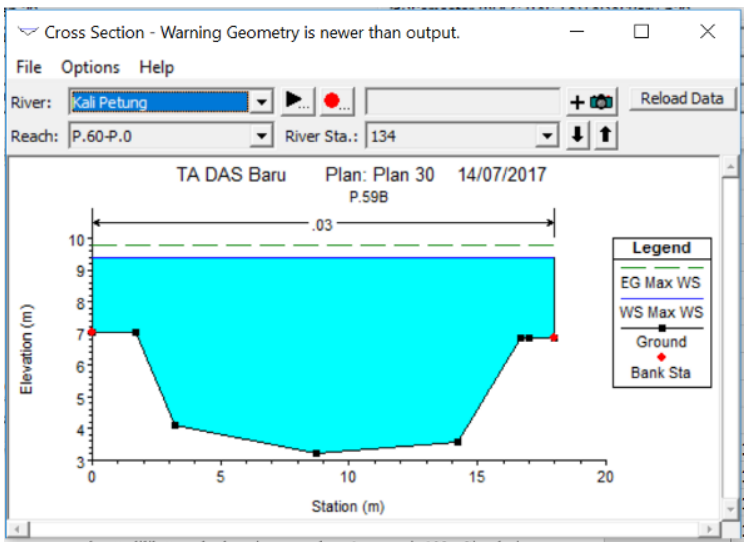

Gambar 10. Hasil Simulasi Run Unsteady Flow Sebelum Dipasang Tanggul STA 134.

\section{Perencanaan Tanggul}

Hampir seluruh cross section sungai mengalami banjir, sehingga harus dipasang tanggul, dengan kriteria berupa tinggi jagaan dan lebar mercu [10], tabel 10 dan 11.

Tabel 10.

\begin{tabular}{cc} 
Tinggi Jagaan Berdasarkan Debit Banjir Rencana \\
\hline \hline $\begin{array}{c}\text { Debit Banjir Rencana } \\
\left(\mathbf{m}^{3} / \mathbf{d e t i k}\right)\end{array}$ & $\begin{array}{c}\text { Jagaan } \\
(\mathbf{m})\end{array}$ \\
\hline$<200$ & 0,6 \\
$200-500$ & 0,8 \\
$500-2000$ & 1 \\
$2000-5000$ & 1,2 \\
$5000-10000$ & 1,5 \\
$>10000$ & 2 \\
\hline \hline
\end{tabular}

(Sosrodarsono, 1995)

Tabel 10

Lebar Mercu Berdasarkan Debit Banjir Rencana

\begin{tabular}{cc}
\hline \hline $\begin{array}{c}\text { Debit Banjir Rencana } \\
\left(\mathbf{m}^{3} / \mathbf{d e t i k}\right)\end{array}$ & $\begin{array}{c}\text { Lebar Mercu } \\
(\mathbf{m})\end{array}$ \\
\hline$<500$ & 3 \\
$500-2000$ & 4 \\
$2000-5000$ & 5 \\
$5000-10000$ & 6 \\
$>10000$ & 7 \\
\hline \hline
\end{tabular}

(Sosrodarsono, 1995)

Berdasarkan tabel 9 dan 10, maka dengan debit banjir rencana 264,32 m3/detik, maka direncanakan lebar mercu 3 meter dan tinggi jagaan 0,80 meter. Salah satu contoh penmpang melintang sungai setelah dilakukan simulasi, gambar 12. Lereng tanggul direncanakan dengan kemiringan 1 $: 1$.

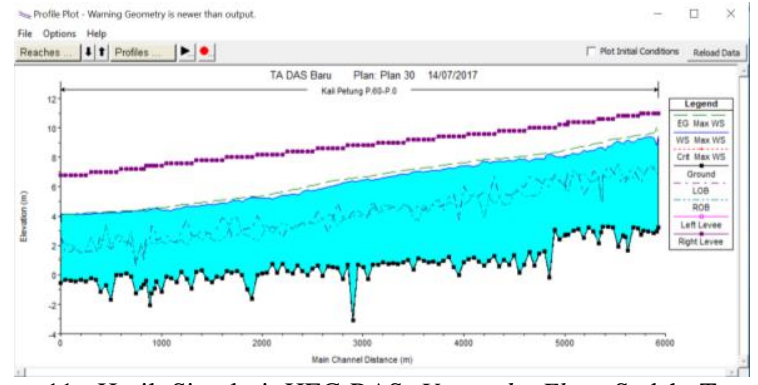

Gambar 11. Hasil Simulasi HEC-RAS Unsteady Flow Sudah Terpasang Tanggul.

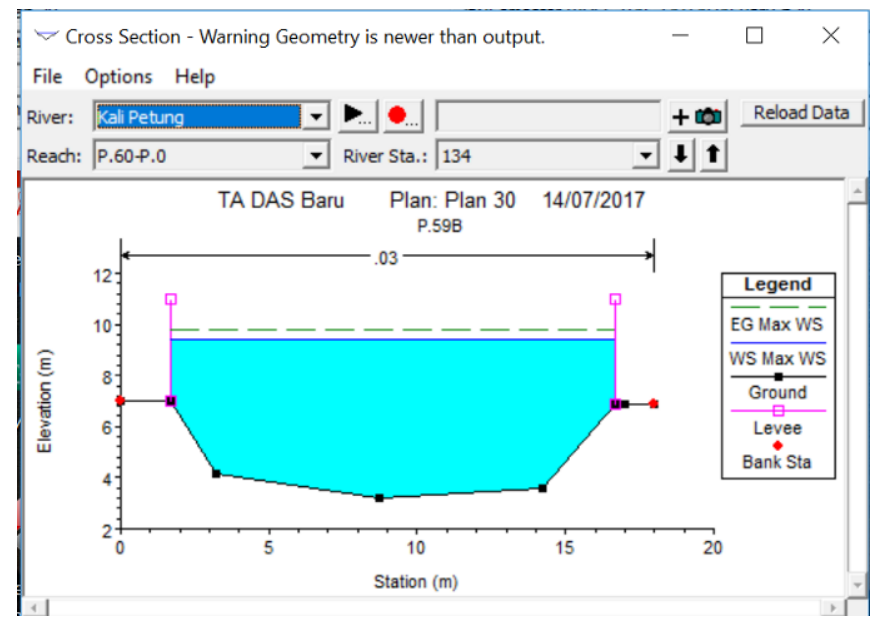

Gambar 12. Hasil SimulasiHEC-RAS Unsteady Flow Sudah Terpasang Tanggul STA 134.

\section{PENUTUP}

\section{A. Kesimpulan}

Kesimpulan yang diperoleh pada Studi ini berdasarkan analisis yang telah dilakukan, antara lain :

1. Besarnya pengaruh hujan terhadap Sungai Petung dapat ditinjau dengan melihat besarnya debit banjir rencana dengan metode Nakayasu sebesar $214,454 \mathrm{~m}^{3} /$ detik pada 4,72 jam.

2. Kapasitas Sungai Petung tidak mampu menyalurkan debit banjir rencana periode ulang 25 tahunan

3. Penanggulangan banjir pada Sungai Petung berupa pemasangan tanggul. Pelebaran Sungai tidak dapat dilakukan karena keterbatasan lahan.

4. Perencanaan penanggulangan banjir Sungai Petung dilakukan sepanjang $5,93 \mathrm{~km}$ dengan cara pemasangan tanggul dengan tinggi $3-5$ meter dengan kemiringan lereng 1:1 dan lebar mercu 3 meter pada STA 134-STA 0.

\section{B. Saran}

Berdasarkan hasil analisis dan perhitungan pada Studi ini, terdapat beberapa saran yang bias dijadikan bahan pertimbangan, yaitu :

1. Dalam pengembangan Kota/Kabupaten Pasuruan, tetap menjaga Daerah Aliran Sungai, terutama DAS Petung. Jika kerusakan DAS semakin parah, maka banjir juga akan semakin parah. 
2. Perlu dilakukan pemasangan tanggul sepanjang $5.93 \mathrm{~km}$ dari muara.

3. Perlunya pemeliharaan berkala, berupa pembersihan sampah di sungai dan pengerukan sedimentasi pada Sungai Petung

\section{DAFTAR PUSTAKA}

[1] Suripin, Sistem Drainase Perkotaan yang Berkelanjutan. Yogyakarta: ANDI, 2003.

[2] Soewarno, Hidrologi: Aplikasi Metode Statistik untuk Analisis Data. Bandung: Nova Publisher, 1995.

[3] B. Triatmodjo, Hidrologi Terapan. Yogyakarta: Beta Offset Yogyakarta, 2010.
D. P. Umum, Rencana Tata Ruang Wilayah Kota/Kabupaten Pasuruan.

[5] S. H. BR, Analisis Hidrologi. Jakarta: Gramedia Pustaka umum, 1993.

[6] S. Rawi, Pengolahan Data Pasang Surut. Bandung: Institut Teknologi Bandung, 1994.

[7] R. Ongkosongo, O., S, Asean-Australia Cooperative Program on marine science Project I: tides and tidal phenomena: Pasang surut. Lembaga Ilmu Pengetahuan Indonesia, 1989.

[8] V. Te Chow, Hidrolika Saluran Terbuka. Jakarta: Gramedia Pustaka umum, 1997.

[9] Davis, HEC-RAS River Analysis System. California: U.S. Army Corps of Engineers Hydrologic Engineering Center, 2004.

[10] S. dan K. T. Sosrodarsono, Hidrologi untuk Pengairan. Jakarta: PT. Pradnya Paramita, 1980. 